\title{
Sour grapes
}

\author{
JAN THERON ${ }^{1}$
}

Practising Attorney and Co-ordinator of the Labour and Enterprise Project (LEP), Faculty of Law, University of Cape Town

\section{INTRODUCTION}

At the end of an interview, while waiting for $\mathrm{M}, \mathrm{I}$ asked a farm worker a question that was not listed on my schedule: "As someone who grew up in this valley, have things in your experience got better or worse?"

The worker concerned, whom I shall call Faan, was 40 years old. The best part of his childhood years must have been in the 1970s. His working life would have started in the 1980s. A colleague who accompanied him had also grown up in the Hex River valley. Both were employed on a farm belonging to a company that owned several other farms in the valley. It was a private company owned, so far as they were aware, by an individual farmer. Let me call him Mr. Q.

One would not have expected Faan to say that things had simply stayed the same. The changes that had taken place in the valley were all too visible. In and around the small town that is the commercial hub of the valley an informal settlement has mushroomed on both sides of the N1. On the town-side of the road it is known as Dixiekamp. On the far side it is appropriately known as Stofland. There is another informal settlement further down the road, in the direction of Worcester. This is "GG camp" (its name evidently inspired by the licence plates of government garage vehicles that visit there).

Faan is a general worker with Grade 12 schooling. That is another indication of a change that had taken place in the valley. Although information specific to the valley is lacking, it is most unlikely one would have found a general worker who had completed his or her secondary schooling in the 1970s and 1980s, when Faan was going to school. What is more, Faan is articulate. In the 1970s, farm workers were not. "It is... difficult to access personal feeling and aspirations of farm workers because they are generally inarticulate", a commentator wrote in a paper delivered at a conference on farm labour in $1976 .^{2}$

On the other hand this perceived difficulty may have had more to do with the social status of the writer, a prominent farmer in the valley, than with a real inability on the part of workers to articulate their aspirations. A worker would have been taking

\footnotetext{
${ }^{1}$ The author would like to acknowledge the assistance of Phamhidzai Bamu in undertaking this research.

2 Graaff "Farming in the Hexriver Valley" SALDRU Farm Labour Conference (September 1976)

Paper No. 42, 1 at 7.
} 
a distinct risk in articulating his or her real aspirations to an employer in the 1970s and 1980s. An appropriate degree of servility was requisite, epitomised by utilising the term "baas" in all references to the farmer, including to third parties such as the researchers. Here, too, was evidence of a change that had taken place. Faan referred to the owner as "Mister".

At any event, my question to Faan prompted a swift response. This was framed as a rhetorical question, as responses often are in working-class discourse. "How can one say things have changed for the better when one's employer (referring to Mr. Q) feeds his dogs a meal intended for his gardener, and gives him dry bread instead?"

Clearly Faan was referring to a specific event. When asked what had happened, and whether he had personal knowledge of it, he explained that he had not witnessed what occurred but that his colleague had. The story went as follows. About three years ago Mr Q's son took the gardener a plate of food: chops left-over from a braai the night before, and bread. Before the gardener had started to eat, Mr Q arrived on the scene. He snatched the plate away from the gardener, stating that this was not suitable food for him. He threw the chops to his dogs and brought the gardener dry bread instead.

One imagines that $\mathrm{Mr} \mathrm{Q}$, if confronted, would present a different account of what had happened. He would deny snatching the plate away. Probably he would advance a persuasive reason for taking it: the food was not good enough for the gardener to eat, perhaps; it was only good for the dogs. But the issue here is not whose explanation is the more persuasive in the court of public opinion. It is rather how Faan and his colleague interpreted their boss's action. Both Faan and his colleague are active members of a union that is regarded as sufficiently representative of workers on the farm. It is therefore likely that their interpretation is one Mr. Q's workers believe, or at least a significant number of them. ${ }^{3}$

Faan's story illustrates the extent to which the paternalist ideology in terms of which employment relations on farms used to be cloaked has been stripped away. ${ }^{4}$ Probably that was Mr. Q's point: 'There are no more free lunches on my farm," one imagines him saying to himself. Perhaps it was a message directed at his son as much as the gardener. But it also suggests there is something atavistic about labour relations in the sector, despite extensive changes in the labour relations regime.

\footnotetext{
${ }^{3}$ The Union is regarded as sufficiently representative for the purposes of stop order deductions in terms of section 13 of the LRA of 1995.

4 Du Toit \& Ally "The Externalisation and casualisation of farm labour in Western Cape Horticulture: A survey of patterns in the agriculture labour market in key Western Cape districts, and their implications for employment justice" Research Report No. 16 Programme for Land and Agrarian Studies (2003) 14; Kritzinger, Barrientos \& Roussouw "Global Production and flexible employment in South African horticulture: experiences of contract workers in fruit exporters." (2004) Sociologia Ruralis 44(1) 17 at 20. According to Du Toit (ibid), "[m]anagement on farms has been characterised by paternalist ideology.... Paternalist ideology served to maintain social control through racial discrimination and also structured the work relationship".
} 


\section{THE AIMS OF THIS PAPER}

Stofland was established in 2006, supposedly as a "transitional" camp for those living in crowded conditions in the formal township, in backyard dwellings and the like. ${ }^{5}$ But the transition to a formal township has not occurred. Instead it and the other informal settlement seem to be expanding, and foreign migrants are a visible presence. There are no non-agricultural job prospects of any significance in the valley. The only conceivable economic rationale for such a concentration of humanity is the prospect of employment on farms in the valley.

Employment creation is a national priority, and it is often said that agriculture (and agro-processing) is (or should be) a sector in which jobs are created. This has not happened. According to official statistics jobs have been shed. ${ }^{6}$ A study on employment in the valley confirms this trend. Despite the fact that the area under cultivation expanded by half, the number of jobs had fallen by 30 percent over a thirty-year period. ${ }^{7}$ How, then, are the job statistics reconciled with burgeoning informal settlements? The most plausible explanation seemed to be a growth of indirect employment.

The primary aim of this study was to investigate whether there had indeed been a growth of indirect employment, and to what extent this was attributable to the labour regime, as well as its consequences for that regime. The term "regime" is used here to denote both labour legislation and the institutions that underpin it, including the trade unions. Indirect employment occurs where employment has been externalised, and workers are "employed" by intermediaries who in turn provide them to a user or client, in this case the farmer. Although employed in agriculture, the business of the employer is in services. To the extent that it is captured at all in official statistics, it is probably reflected as employment in services. $^{8}$

To seek to attribute the form employment takes to a particular labour regime is one thing. It is quite another to attribute economic consequences to the labour regime, such as the failure of the economy to generate employment or the loss of jobs in agriculture. Yet there is powerful institutional support for such an argument. Although the global economic crisis that has arisen at the time of writing calls into question some of its premises, it is nevertheless an argument that must be taken seriously, not least because of the doggedness with which it is pursued. ${ }^{9}$

\footnotetext{
${ }^{5}$ Interview, 13 November 2008.

${ }^{6}$ According to Statistics SA, employment in agriculture has been in fairly steady decline since September 2001. Employment in agriculture accounted for 7,8 percent of total employment, or one million jobs, in September 2007: Labour Force Survey September 2007 vi Table E.

${ }_{7}$ Conradie "What do we mean when we say casualisation of farm work is rising? Evidence from fruit farms in the Western Cape" Agrekon 46(2) (2007) 173.

8 Theron "The shift to services and triangular employment: implications for labour market reform" (2008) 29 Industrial Law Journal 1.

${ }^{9}$ An acknowledged cause of the global financial crisis was US home-owners defaulting on their mortgages. The need for better regulation of financial markets is now generally acknowledged, and the notion that markets are capable of regulating themselves (propagated by Hayek) is now discredited. It is less often acknowledged that one of the reasons US home-owners defaulted can surely be attributed to unregulated labour markets, in that ever fewer borrowers have the security of a standard job.
} 
A second aim of this paper is to interrogate the argument which in broad terms goes as follows: labour legislation has served to introduce "rigidities" in the labour market and trade unions (through collective bargaining) have pushed up minimum wages to unrealistic levels. The cumulative effect has been that capital is not willing or able to employ. Taken a step further, it is argued that labour regime is itself an obstacle to the alleviation of poverty.

The World Bank, through its "Doing Business" survey, is driving a process whereby labour and other regulations supposedly impacting on business are "costed", purportedly objectively. Countries are then ranked according to the scores achieved. Ostensibly this survey is not concerned with "deregulation" as much as reform. However, a country that has no labour regulation at all will obtain a most favourable rating as compared with a country with labour regulation, regardless of its content.

In a local variant of essentially the same argument, organised labour is portrayed as representing vested interests with no interest in opting for what is the optimal solution for the poor in an economy with high unemployment, namely low-wage employment. ${ }^{10}$ This situation is perpetuated because "the poor" do not have the political clout to challenge these vested interests and occupy institutional forums, such as NEDLAC, where policy is formulated.

Disregard for the time being an obvious question that this analysis begs, namely how "the poor" are expected to achieve political clout without organisation and what form such organisation should take. By invoking "the poor", the protagonists of this argument seek to secure the moral high ground. Their antagonists can be regarded as those who, out of a misguided concern for workers' rights, are protagonists of the labour regime. Mindful that "the poor" is not a coherent category, they pinpoint (in my opinion, correctly) a weak point in the argument of their antagonists and, more broadly, in the tradition of Marxist scholarship. This is its failure to analyse or address the growth of inequality in what had hitherto been termed the working class in the period since transition to democracy.

Accordingly, with the object of understanding inequality in society, Seekings and Nattrass resort to a class analysis of their own. In this analysis the occupation of members of households is a critical determinant of their class position. ${ }^{11}$ At the same time they argue that what they term the "labour contract" (by which, it appears, they mean a written contract of employment) is a key distinction between what they (tentatively) categorise as the "core working class" as opposed to a "marginal working class".12 Farm workers are posited as part of that marginal

10 Seekings J \& Nattrass N Class, Race and Inequality in South Africa Yale University Press, New Haven (2005) at 380-381.

11 Ibid 241.

12 "In the South African context, as in Brazil and many other southern societies, a large number of workers sell their wages without any formal contract: their conditions of work are quite distinctive and they are especially vulnerable to employers. These clearly include many farm and domestic workers....": Seekings \& Natrass op cit 248. The idea that the contract is a critical determinant of class position apparently derives from Goldthorpe, who differentiates between "service relationships" and "labour contracts" to distinguish the class locations of certain groups: ibid 241. 
working class, and occupy the same structural position in society as what is referred to as an "underclass".13 A subsidiary aim of this paper is to examine the validity of this "class analysis".

The different aims of this paper are related. It would be naïve to suppose that the argument that the labour regime constrains employment creation is not politically motivated. But if it were perceived to be politically motivated, it would not fly. Hence it is necessary to make an economic case that demonstrates a causal relationship between the extension of labour regulation and job losses. The appropriate policy intervention then becomes obvious. Labour regulation must be reformed (or scrapped). The existence of a "marginal working class" that gains no benefit from labour legislation lends political weight to the clamour for its reform. At the same time the argument that labour regulation constrains job creation is a counter to "inappropriate" reforms that would extend the benefits of regulation to the marginal working class. The paper seeks to interrogate and challenge this line of reasoning.

\section{POINTS OF DEPARTURE}

There are a number of difficulties with any endeavour to establish a causal relationship between law and economic consequences, or vice versa. Indeed in terms of the theory of autopoiesis such an endeavour is fundamentally misconceived. This theory holds that law is essentially a self-referential system of communication that is not able to intervene directly in social or economic processes. ${ }^{14}$ This is not to say that law has no effects on these processes, or these processes on law, or that one should not attempt to determine them. But it should be understood that these effects are indirect, and contingent.

Attempts to cost the impact of regulation economically, as in the World Bank's "Doing Business" survey, are typically founded on artificial and simplistic conceptions of law. This is exemplified by the erroneous belief that it is possible to read legal rules from the text of legislation without regard for the regime of which it is part. ${ }^{15}$ It is the legal regime that determines how legislation is interpreted in accordance with other rules and applied in practice.

To determine the impact of a particular regime, then, detailed case studies are needed in which it is possible to take account of law's complexity. The agricultural sector in a number of respects represents an ideal opportunity for undertaking such a study. Since the advent of democracy, in the space of ten years, the legal regime regulating labour relations in agriculture has been more profoundly transformed than in any other sector. At the same time the agriculture sector provides a lens through which to scrutinise the notion of a "marginal working class" of which its workforce is supposedly part.

\footnotetext{
${ }^{13}$ Seekings \& Natrass op cit 336-339.

${ }^{14}$ It is not possible to give an exposition of this theory here. See, however, Teubner G Law as an autopoietic system Blackwell (1993).

15 Benjamin \& Theron "Costing, comparing and competing: Developing an approach to the benchmarking of labour market regulation" University of Cape Town, DPRU Working Paper 07/131 (2007).
} 
The transformation of the legal regime in agriculture began in 1993 with the partial incorporation of farm workers into the previous labour regime. ${ }^{16}$ Full incorporation occurred in 1997 with the adoption of a new Basic Conditions of Employment Act (BCEA); henceforth farmers were expected to comply with a relatively workerfriendly set of conditions of work as well as the labour standards introduced by the Labour Relations Act (LRA). ${ }^{17}$ In the same year the Extension of the Security of Tenure Act (ESTA) ${ }^{18}$ was introduced with the object of protecting the security of tenure of occupiers of land, including (notably) farm workers in occupation of houses on farms. Then, in 2003, a sectoral determination introduced a minimum wage. ${ }^{19}$

When minimum wages in the sector were first promulgated in 2002, the farmers' association AgriSA estimated that it would lead to significant job losses. ${ }^{20}$

There has been a marked decline in employment in sub-sectors such as wheat and dairy. But trade liberalisation in agriculture occurred over roughly the same period as labour legislation was extended to agriculture. ${ }^{21}$ Both are sub-sectors acutely affected by the increased competition that resulted from lowering tariffs. If one was looking for a smoking gun, trade liberalisation is the most likely suspect. ${ }^{22}$

At the same time, the extent to which the regime was transformed should not be exaggerated. The minimum wages prescribed were decidedly moderate and would probably not have represented an increase at all in certain areas. ${ }^{23}$ The minimum

16 The Basic Conditions of Employment Act 3 of 1982 and the Unemployment Insurance Act 30 of 1966 were both extended to farmworkers in that year. At the same time the Agricultural Labour Relations Act 147 of 1993 was introduced. A distinction was drawn between farm workers and other employees in respect of labour relations. See in general Le Roux "Agricultural Workers: a historical and contemporary perspective" University of Cape Town, Institute of Development and Labour Law Monograph Series 1/2002 ((2002).

${ }^{17}$ Act 66 of 1995.

${ }^{18}$ Act 62 of 1997.

${ }^{19}$ Sectoral Determination 8, Farm Worker Sector (superseded by Sectoral Determination 13 in 2006 - Editor). The sectoral determination and ESTA are probably the two legislative provisions that have had the greatest impact on the sector.

${ }^{20}$ Business Day 27 February 2002, cited in Kritzinger, Barrientos \& Rossouw "Global Production and flexible employment in South African horticulture: experiences of contract workers in fruit exporters" Sociologia Ruralis 44(1) (2004) 17 at 21. Although minimum wages for the sector were promulgated in 2002, it was only in March 2003 that the new minimum wages eventually came into effect.

${ }^{21}$ Trade liberalisation refers to the reduction of tariffs and related measures pursuant to South Africa's obligations in terms of international trade agreements to which it was part. In fact, South Africa went far beyond what was required in terms of the Uruguay Round Agreement on Agriculture (URAA), resulting in one of the "least state-protected agricultural sectors in the world": Tilley S "An examination of market-assisted reform in South-Africa" International Labour Resource and Information Group (ILRIG), Cape Town (2002) at 4.

22 Theron, Godfrey \& Visser "Globalization, the impact of trade liberalization, and labour law: the case of South Africa."' ILO, International Institute for Labour Studies, Discussion Paper DP 178/2007 (2007). An increase of tariffs on both these commodities was subsequently contemplated: see "Import tariffs on food in line for comeback" Cape Times Business Report 20 October 2008.

23 Thus in area A, comprising the areas of prime agricultural importance, the minimum wage prescribed was R800 per month while in area B it was R650 per month. The latter certainly represented less in real terms than, according to a 2001 report of the Employment Conditions Commission, workers were on average earning in 1996. 
wage in 2008-2009 stood at R1 090 per month. ${ }^{24}$ More profoundly, the regime instituted by the above-mentioned legislation has not displaced the common law to the extent that is sometimes supposed. Prior to 1993 this was a common law regime in which the doctrine of "sanctity of contract" had pride of place. Simply stated, this doctrine means that the parties to a contract are bound by its terms notwithstanding any inequality of power between them. ${ }^{25}$ In the sphere of labour relations of farms this meant that the employment relationship was determined by the terms of the contract concluded between farmer and worker. It is immaterial whether or not the contract is in writing. ${ }^{26}$ In the context of externalisation, the issue is rather with whom there is a contract and under what circumstances (if any) the person who actually provides the work, and who is in an economic sense the real employer, may be held accountable.

\section{NOTES ON METHODOLOGY}

The impact of labour legislation should be more limited and easier to isolate in a sub-sector oriented toward exports, such as deciduous fruit. ${ }^{27}$ This was the primary reason that the Hex River valley was selected as the site of this research project. ${ }^{28}$ Initially it was envisaged conducting the field-work for this project by taking a sample of farms in the area and interviewing the farmer as well as his workers. Other researchers have also used the farmer as their point of contact, and research

\footnotetext{
${ }^{24}$ For 2009-2010 it was increased to R1 232 and for 2010-2011 to R1 317 - Editor. See Sectoral Determination 13: Farm Worker Sector at http://www.labour.gov.za/legislation/sectoraldeterminations/sectoral-determination-13-farm-worker-sectorhttp://www.labour.gov.za/ legislation/sectoral-determinations/sectoral-determination-13-farm-worker-sector (accessed 22 February 2011).

25 What I refer to as a doctrine comprises a cluster of principles including that reflected by the Latin maxim pacta sunt servanda which requires "exact enforcement of contractual obligations created in circumstances which are consistent with freedom of contract and consensuality", and the notion of "privity of contract": see Van der Merwe, Van Huyssteen, Reinecke \& Lubbe, Contract- General Principles 3ed Juta (2007) at 11. Cockrell's concept of the "hegemony of contract" is also relevant in this context. He argues that contract law occupies a privileged position in relation to other branches of law, although the relationship to labour law is not expressly considered. See Cockrell "The Hegemony of Contract" (1998) 114 South African Law Journal 286.

26 Section 29 of the BCEA requires that an employer provide written particulars regarding the employment of a worker. Where the employer fails to do so there would be a breach of a legislative provision. To this extent failure to comply with this provision may be an indicator of informality. Beyond this there is no conceptual or empirical basis for attaching any particular significance to whether a contract is in writing.

27 This is not to discount that the export market for deciduous fruit has also changed as a result of the ascendance of retail chains in the global North and other factors. It has been argued that there has been a shift from a supplier-driven to a buyer-driven market: Kritzinger "Global markets, employment restructuring and female labourers on Western Cape fruit farms" Acta Academia (2005) 37(1) 99 at 105; Greenberg "Women workers in wine and deciduous fruit global value chains" Report for Women on Farms Project (2003) at 4. Even so, it has remained labour intensive: Kritzinger op cit at 101.

${ }^{28}$ Grapes are the third largest agricultural export earner after wine and citrus fruit: Edwards et al "The position of women workers in wine and deciduous fruit value chains" SANPERI Development Consultants; report commissioned by Women on Farms Project (2008) at 18. In 2004 the Hex River valley contributed 37 percent of the table grape crop: Deciduous Fruit Producers Trust, 2004, cited in Conradie (fn 7 above).
} 
projects that rely exclusively on data provided by the farmer are not usually discounted for this reason. There are obviously practical considerations that make such an approach necessary. There are also data and perspectives that only the farmer would be in a position to supply.

Yet if one is concerned with labour relations, and how employment is structured, reliance on the farmer is problematic. However well-intentioned the farmer may be, interviews arranged through the farmer would make it more difficult to obtain the workers' perspective. At the same time there would be real practical difficulties in reaching the most vulnerable sections of the workforce that we were most concerned should not be excluded.

Ultimately the methodology adopted was dictated by considerations of realpolitik. If farm workers were to be interviewed at all, it would have to be before the peak season. Precious weeks were wasted in negotiating with the employers' association representing farmers in the valley. The association was concerned that, if it was to play any role in facilitating this research, there should be no mention of the area that we were researching. ${ }^{29}$ The association was also not prepared to supply a list of its members. It was decided to abandon interviews with the farmers once it became clear that there was no realistic prospect of being able to set up a sufficient number of interviews before peak season and once it transpired there was a way in which we would be able to access farm workers without going through the farmers.

$\mathrm{M}$ is the secretary of a small regional union based in Worcester whom I knew. It turned out that the union had organised 25 farms in the valley and was planning to launch a branch in the near future. ${ }^{30}$ Researchers attended this meeting and arranged to interview workers. $\mathrm{M}$ put me in contact with $\mathrm{W}$, who styled himself a contractor and was resident in the valley. W was keen to be interviewed, and interviews were arranged with him and other contractors. As well as M herself, a community leader and an official of the Department of Labour resident in De Doorns were interviewed. An official of another union operating in the valley was also interviewed telephonically.

Semi-structured interviews were conducted with farm workers arranged through M's union and with the contractors. The interviews with $\mathrm{M}$, the community worker and the Department of Labour official were unstructured. In the same week as these interviews were being conducted, and just as the peak season was about to commence, the heavens exploded and there was serious flooding in the valley. Stofland exploded a day or so later, with residents blockading the national road (the $\mathrm{N} 1$ ) over issues to do with the provision of services. ${ }^{31}$

As already indicated, foreign migrants are a visible presence in Stofland. First there were migrants from Lesotho staying in a section of the settlement known as

\footnotetext{
29 This is indicative of the fear of being stigmatised that prevails amongst farmers, arguably a positive consequence of the power of the retail chains of the global North and the fair-trade movement.

${ }^{30}$ We were informed by the community leader that there were approximately 240 farms in the valley, but were not able to confirm this.

31 This was in November 2008.
} 
Maseru. Now there are migrants from other African countries as well, notably Zimbabwe. Because I had the assistance of Zimbabwean researchers, and on the assumption that Zimbabwean workers would probably represent the most vulnerable section of the seasonal workforce, contact was made with a Zimbabwean resident in De Doorns who was also the pastor of a church ministering to Zimbabwean migrants. Interviews were conducted with members of this church who were employed on farms by various contractors.

In the main, therefore, the research is based on three categories of "workers". The first were resident on the farms and unionised. The second were Zimbabwean migrants. The third were the contractors. I will explain the categorisation of the contractors as workers below.

\section{THE HEX RIVER VALLEY THEN AND NOW}

There can be few localities that lend themselves as well to a project on farm labour as the Hex River valley. Geographically bounded by mountains on either side of the Hex River, access from the north or south is through a mountain pass. It is a selfcontained area devoted to the production of a single product - table grapes. Given also that it is a comfortable drive from Cape Town, it is not surprising that it has generated its own literature.

As well as the paper already referred to, ${ }^{32}$ commentators on farm labour that have focused on the valley include a 1976 study from the perspective of a labour economist, ${ }^{33}$ comparing the situation in the Hex River Valley with that of the Elgin apple farming region. More recently, there has been a study on externalisation and casualisation of farm labour in key farming districts in the Western Cape ${ }^{34}$ and what might be interpreted as a response, again from the perspective of a labour economist. ${ }^{35}$

Table grapes is a relatively labour-intensive crop. Labour, then and now, is primarily drawn from within the valley: either from workers living on the farms or from the town of De Doorns itself. It would therefore seem ideal terrain for a trade union wishing to recruit farm workers as members. Of course there were no trade unions organising farm workers in 1976, and it seems the history of trade union organisation in the valley only began post-1994. At the time of writing there are two, perhaps three trade unions with members in the valley. Although none can be said to have a commanding presence, the union M works for is clearly the largest.

It does not seem the labour process has changed much in the last thirty years. In about mid-November farmers begin to prepare for the season. The peak season usually begins in early December and is known as "groendruiwetyd", or thinning season. This is the most labour-intensive part of the process. Workers remove the small and undeveloped berries from the bunch, over a period of about six weeks.

\footnotetext{
32 Graaff (fn 2 above).

${ }^{33}$ Levy "Seasonal migration in the Western Cape" SALDRU Farm Labour Conference (September 1976) 87.

34 Du Toit \& Ally (fn 4 above).

${ }_{35}$ Conradie (fn 7 above).
} 
Thereafter the grapes are picked, and packed. ${ }^{36}$ This takes place over a period of three months, ending in about May. They are pruned in July or August.

However, contrary to what some have argued, ${ }^{37}$ the manner in which labour is utilised appears to have changed significantly since Levy's study. To appreciate the nature and extent of the change, it is useful to consider how the significance of the categories of "permanent" and "seasonal worker" has changed. "Permanent worker" refers to someone who is employed full-time on a contract of indefinite duration. ${ }^{38}$ Then and now, permanent workers resided on the farm in houses provided by the farmer. However whereas formerly the conditions of the workers' tenancy were unregulated, ESTA now applies. ${ }^{39}$

"Seasonal worker" refers to someone employed on a seasonal basis. It does not seem that farmers in the valley relied on seasonal workers resident on the farm to the same extent as in other fruit-growing areas. ${ }^{40}$ Where seasonal workers were resident on the farm, however, they were assumed to be women and the spouses of male farm workers. They are also described as such in the literature. ${ }^{41}$

Whether resident on or off the farm, the identity of the employer of seasonal workers was not in doubt. This was the farmer. Seasonal workers, in turn, could be distinguished from casual workers. Although the term "casual worker" had no precise legal application in the farming context, it did have elsewhere. It was someone employed for not more than three days in any week. ${ }^{42}$

During the six-week thinning season there had always been an influx of workers from off the farm. These were workers employed directly by the farmer, sometimes with the assistance of a local intermediary, sometimes in terms of a long-standing arrangement, from the nearby towns of Touws River and Worcester as well as De Doorns itself.43 Even so, there was previously a rough equivalence between the number of workers resident on the farm and those who were not. ${ }^{44}$ At all other times of year the seasonal workers resident on the farm far outnumbered workers from elsewhere.

Nowadays it appears that the overwhelming majority of seasonal workers are not resident on the farms. This is true not only during the thinning season, but also

\footnotetext{
${ }^{36}$ Levy (fn 33 above).

${ }^{37}$ Conradie (fn 7 above).

38 These can be regarded as the minimum defining characteristics of a standard employment relationship.

${ }^{39}$ Although not strictly-speaking labour legislation, ESTA is implicated in a trend towards hiring off-farm labour (to avoid the obligations ESTA imposes on the land-owner). However, Greenberg (2003: 15) argues that the trend began before the passing of ESTA.

40 In the interview with the Department of Labour official, it was suggested that it had never been the practice to source seasonal workers on the farm, as distinct from an area such as Grabouw where this was the practice.

${ }^{41}$ Levy (fn 33 above).

42 Basic Conditions of Employment Act 3 of 1983.

${ }^{43}$ Levy (fn 33 above).

${ }^{44}$ See Levy (fn 33 above) Table 4 at 94. Levy's study provided data from 18 farms employing a total of 649 permanent workers (including 94 African workers on one-year contracts). There were 683 seasonal workers resident on the farms and 136 children employed in the thinning season. The number of workers employed from elsewhere in the thinning season was 1655 . At other times it dropped to less than 80.
} 
at other times of the year. This is in keeping with a general trend in deciduous fruit to recruit workers who live off-farm. ${ }^{45}$ Off-farm workers are engaged and transported to work by intermediaries. These are referred to in the literature and the area as contractors. ${ }^{46}$ However, although a contractor is supposedly different from a labour broker in that the former plays a more active role in supervising the activities of workers provided to a client, ${ }^{47}$ from a legal perspective it is questionable whether there is substance in the distinction.

A labour broker is what in post-1994 labour legislation is referred to as a temporary employment service (TES). ${ }^{48}$ In recognising labour brokers as the employer of the workers they procure or provide to an employer, it has been argued that labour legislation itself has created the legal space employers needed to restructure the employment relationship by means of a process of externalisation. ${ }^{49}$ There are no special concessions to accommodate the consequences of labour broking in agriculture in the Sectoral Determination. ${ }^{50}$ Consequently the insecurity that characterises the relationship between the farmer and labour broker means that workers employed by a broker are in an even more insecure position. ${ }^{51}$

\section{WHAT THE PERMANENT WORKERS HAD TO SAY}

Fifteen workers resident on farms were interviewed. Only one, a 21-year-old woman living with her parents, was a seasonal worker. She was interviewed at her home on the farm, on which about half the interviews were conducted. ${ }^{2}$ There were a number of other workers present where interviews were conducted that for reasons of time it was not possible to interview. None of them were seasonal workers. A young man who had recently matriculated said he was a seasonal worker. But it turned out he was in fact continuously employed. He had simply been told he was not permanent.

The fact that so few seasonal workers were identified from amongst farm residents provides some confirmation that the phenomenon of a seasonal worker resident on the farm is relatively unusual. It must however be acknowledged that the interviewees were from only seven farms. ${ }^{53}$ Perhaps more telling was the fact that, at the time of the interviews, preparations for the season were underway and teams of workers from off the farm were already at work, although not in the

\footnotetext{
45 Greenberg (fn 27 above) at 15.

46 Conradie (fn 7 above); Jacobs “Farm Workers, Job Security and Labour Contractors" Elsenburg Journal 5(22) (2008).

47 Jacobs (fn 46 above).

48 Section 198, LRA of 1995; s 82, BCEA of 1997.

49 Theron, Godfrey \& Lewis "The rise of labour broking and its policy implications" Institute of Development and Labour Law, University of Cape Town, Development and Labour Law Monograph Series, 1/2005 (2005).

50 Clause 33, Sectoral Determination 13.

51 Kritzinger (fn 27 above) at 113-114.

52 In some instances this was farm land, without the permission of the farmer, and in some instances it was on public roads adjacent to farm houses.

53 Four were African and the remainder were coloured. Their ages ranged from 21 to 59 years. Two were matriculants and two, both African men, had no schooling whatsoever.
} 
numbers there would be during peak season. The consensus was that the off-farm workers far outnumbered those resident on the farm.

Strange to say, the workers resident on farms did not know much else about the off-farm workers because they had nothing to do with them. It appears that the farmers went to some trouble to ensure that off-farm workers had as little contact with residents as possible.

Nine of the workers interviewed were men and six were women. Where husband and wife were employed, it seemed common that both were permanent. More significantly, at a number of farms the number of women who were regarded as permanent exceeded the number of men. Indeed, it may be because women tend to outlive their spouses that they outnumbered the men.

All were members of M's union, so the sample is skewed. On the other hand, it is not apparent from the outcome of the interviews in what respect membership of a union could have skewed the results. For membership of the union (thus far, at least) seems to have had little impact on the conditions of work. Perhaps the most striking finding to emerge from the research was the uniformity of conditions of employment across different farms, unionised and non-unionised.

All the workers earned the minimum wage or slightly more. This translated to R1 100 per month. Workers doing more skilled jobs earned somewhat more: one tractor driver earned R1 118 a month, another R1 364. The highest-earning worker interviewed was a lorry driver earning R1 760. This represents a differential of about 60 percent between unskilled and skilled.

There was not an issue in the valley of farmers failing to pay the minimum wage to the workers they employed. A Department of Labour official confirmed that there had been no complaints of underpayment in the valley that he was aware of. The only such complaints received concerned the workers employed by contractors. ${ }^{54}$ It is probably not surprising that there is compliance with the sectoral determination regarding minimum wages. It is an affluent area. Farmers in the valley ought to be better able to afford the minimum wage than most. It is also not likely there would be such flagrant non-compliance within half an hour's drive from a regional office of the Department of Labour.

Rather, the allegations of non-compliance concerned subtler issues, such as whether a farmer was justified in deducting rent for housing which had been completed years before and which was not maintained. Or whether a farmer was entitled to deduct monies from workers' wages for repairs when he charged rent. Or whether deductions for electricity were not being inflated. Amongst the seven farms there was only one that did not charge rental at all. In that instance the farmer was planning to renovate the cottages, after which rental would be charged.

One had little sense from the workers interviewed that the wage itself was a burning issue. On the one hand this seemed strange. Workers, particularly those approaching retirement age, cannot have failed to be aware of the amount of a social grant. A family in which only one member was employed would be no better off

54 The farmer is, however, jointly and severally liable in terms of s 82(3) of the BCEA for underpayment of wages and other violations of the Sectoral Determination. 
than a family in which all were unemployed but there was a recipient of a social grant. 55 On the other hand there appeared to be a perception that the wage was akin to the social grant, as something that the government determined and which workers were obliged to accept. There was no farm in the sample at which the union bargained collectively and, so far as it was possible to establish, no farm in the valley at which bargaining took place at all. ${ }^{56}$

The only issue about wages that was raised concerned the differential between the daily rate workers resident on the farm earned and the rate contractors paid workers. This, according to different permanent workers at different farms, was R60 as against the R50 seasonal workers resident on the farm earned. When this differential first came too light, it seemed most improbable that off-farm workers could be earning more than those resident on the farm. However, a number of interviewees at different farms confirmed that this was indeed the case.

The ostensible justification for this differential was that workers who were not resident on the farm had to pay for rented accommodation and therefore had higher costs. At one farm the permanent workers were sufficiently angry about the differential to have confronted the farmer and demanded equal pay for equal work. The farmer acceded to the demand.

It also emerged that on more than one farm workers from Touws River and Worcester had been recruited directly by the farmer, as well as workers recruited via a labour broker. Probably the pattern of recruiting workers from Touws River and Worcester is a residue of the practice documented in the 1970 s. $^{57}$ These workers were transported back and forth on a daily basis in an open lorry. But in one instance a team of workers from Touws River stayed in a vacant farm house and were transported back home on week-ends. They were also paid R10 more than the workers resident on the farms.

Most of the workers had signed written contracts with the farmer, and quite often it appeared that the contracts were renewed annually by the farmer. This was probably done on the advice of one of several labour consultants who advise farmers in the area, for reasons that are not clear. However, none of the workers had a copy of the contract they had signed, to which they were lawfully entitled. ${ }^{58}$ This was one of the issues the shop stewards of M's union wanted to take up.

The fact that, close to 15 years after trade unions in agriculture were recognised, workers were unable to achieve something as simple as obtaining a copy of their contracts of employment is an indictment of the trade union movement. A worker who was a member for four or five years of one of the first

\footnotetext{
55 This of course assumes that there is no distinction in respect of housing.

56 M's union had no arrangement to bargain collectively at any of the farms where it was sufficiently representative. The other union interviewed, an affiliate of the Congress of South African Trade Unions (COSATU), had been organised in the valley longer but was only representative at one farm and had no bargaining arrangement there.

57 Levy (fn 33 above).

58 In terms of the BCEA; see fn 26 above.
} 
unions to organise in the valley was scathing about his experience. "You hear what they say", he said, "and wait to see what happens." In his case, nothing did.59

There was also a story of a union official who went to see Mr Q on behalf of the workers he had recruited. The official never reported back to the workers. The next time he was seen in the area, he was driving a new Venture. Workers drew their own conclusions. "Stofland is filled with workers who have lost the jobs because of unions they joined that did nothing to help them", said a worker who was interviewed.

The other issue affecting workers at three farms concerned their membership of a provident fund. The fund was managed by one of South Africa's major insurance houses, and the tenor of the workers' complaint was that workers were compelled to belong to it. Also the payout in the event of a worker resigning was minimal. This was probably because the rules of the fund penalised workers who resigned by allowing the employer to withhold its contributions. However, the workers were not provided with the rules.

The fact that only three out of seven farms had a provident fund, and that none had any kind of medical benefit fund, suggests that there are not many fringe benefits for farm workers. ${ }^{60}$ Probably for this reason other insurance houses have identified farm workers as a potential new client base. At a meeting of M's union held while this research was underway there was a speaker who was also a parttime broker for an insurance house who emphasised the importance of workers making provision for their retirement.

\section{WHAT THE ZIMBABWEANS HAD TO SAY}

The Zimbabean migrants, according to $\mathrm{W}$, were dropped off on the N1 in the middle of the night and taken to a "white house". In this house they would be provided with free accommodation and food for a period of two weeks. During this period the new arrivals were expected to find work and accommodation. Then they were expected to start contributing to the "white house" to open the way for the next batch of migrants to be treated in a like manner. The "community"' had tried to locate this "white house". No-one had ever been able to do so.

It is not clear whether this "white house" is a rural legend, or a metaphor for the networks that had brought the migrants to the valley, or an actual dwelling. But it was clear that the word was out that the there was money to be made in the valley, and Zimbabwean workers interviewed had travelled a long way, sometimes by circuitous routes. Some were from Harare. Some were from farms in Zimbabwe. Some had travelled to the Department of Home Affairs in Port Elizabeth to get their papers in order so as to work in the valley. Probably they went to Port Elizabeth because the same networks that brought them to the valley had informed them that

\footnotetext{
59 This trade union was the COSATU affiliate referred to above.

60 The manner in which medical treatment of workers is dealt with by the farmer is a further indication of the uniformity of employment conditions. Invariably the worker would see a medical practitioner in town on the farmer's account, and the cost of the consultation and medication would be deducted from the worker's wage.
} 
their prospects were more favourable there than in Worcester or Cape Town because of a quota system utilised by Home Affairs.

All but two of the fifteen Zimbabwean workers interviewed were new arrivals. Several were following a family member or spouse who had already found work in the valley. There were eight women and nine men. One, who was not a new arrival, had been working in the valley for two years and had started out as a seasonal worker employed by a contractor. Now he was employed permanently as a security guard on one of the farms. The other had also been employed through a contractor initially but was now employed directly by the farmer. Nevertheless, both lived off the farm in the informal settlement. These were examples of "permanent" workers living off-farm.

Bar the two already mentioned, all the workers interviewed were employed through contractors. They referred to the contractors as "spanners". Probably the term derives from the Afrikaans word for team, "span", but somehow the English connotation of tightening bolts seems appropriate. The "spanners" they had to do with stayed in the town. Some were in the formal part and others in the informal settlement. There were also two Zimbabweans amongst them. The "spanners" had dealings with various farmers and would charge a once-off placement fee of R25. However, where a worker referred another worker to the "spanner", the fee would sometimes be waived.

The "spanner" would go round to the farm to check how his workers were doing from time to time, but there was little indication that they provided ongoing supervision. The farmer, of course, utilised his own supervisors. Sometimes the "spanner" would also appoint a Zimbabwean on-site to supervise the workers on the basis that such a supervisor would be better able to communicate with the workers. Workers were paid in cash, in an envelope with their name on it, but with no other particulars provided. No-one signed a contract with the "spanner".

The workers were employed on different farms in the valley. Three were working on one of the farms belonging to Mr Q's company. Three did not know the name of the farm where they worked. The remainder were on different farms from those on which "permanent" workers interviewed were working. However, all were paid at what we had already established was the going daily rate for off-farm labour, namely R60. The exception was the worker continuously employed. He earned R50 a day in line with the minimum wage. This was also in line with the practice already identified whereby "permanent" workers may earn less than their seasonal counterpart, except that he, as already indicated, did not stay on the farm.

This worker paid a rental of R400 per month. It was not an unusually high rental for a room in a shack in Stofland. All the workers were staying in the informal settlements, where they usually rented a room from compatriots who had been in the valley for longer. The room was often also shared with their compatriots. Some were shared by up to ten workers.

Seven of the workers interviewed had completed their 0 Levels, one had completed his A Levels and two had university degrees. Compared to the populace 
of the valley they were highly educated. ${ }^{61}$ They were also regarded as good workers. It is scarcely surprising, then, that they were resented as taking away jobs from the local community. The workers complained that they were treated like dogs. During the blockade on the N1, they were threatened with beatings if they went to work.

\section{WHAT THE “SPANNERS” HAD TO SAY}

There was a perception that farmers were encouraging the influx of Zimbabwean migrants. Permanent workers interviewed also reported that farmers were assisting migrants to get asylum papers from the Department of Home Affairs. Zimbabwean migrants confirmed that this did indeed happen. A contractor claimed there were farmers who were hiring migrants directly from the township and paying them R30 a day. ${ }^{62}$ Tensions had been mounting about lorry-loads of workers seen leaving Stofland. "They cannot do the work", it was claimed. "The workers who know the work are not given a chance."

The three contractors interviewed had all been involved in a bid to establish an association, of which $\mathrm{W}$ had been the chairperson. ${ }^{63}$ One had only completed Grade 7 , but the other two had secondary schooling and $W$ had matriculated. $W$ had previously been employed by the state but had been boarded due to ill-health. He lived in what could pass, in a small rural town, as a lower middle-class house.

All three had essentially the same grievance. They were interviewed near the start of the season in November and had had no work since April, whereas the previous year they had been busy for most of this period. They believed they were not getting contracts because they had registered as employers with the Department of Labour and Compensation Fund. ${ }^{64}$

It is believed that labour brokers or contractors in agriculture generally pay piece-rates. Piece-rates do apply in the peak season, but this is a long established practice that applies both to those employed through contractor and those employed directly by the farmers. During peak season the contractors had to maintain a schedule recording each worker's output. Sometimes workers earned a R1 000 a week. Outside of peak season, the contractor maintained that they paid the minimum wage to their workers. There were about 50 registered contractors in the valley, it was claimed. ${ }^{65}$ Now their association had collapsed and most of the registered contractors were without work.

It was, after all, easy for someone to set himself or herself up as a contractor. A woman might see a farmer driving in town and call out: "are you looking for

\footnotetext{
61 See note 53 above.

${ }^{62}$ Researchers attempted to verify this allegation but were not able to.

${ }^{63}$ Hex River Valley Agricultural Contractors' Association.

${ }^{64}$ Registration as an employer with the Department of Labour means the contractor would be obliged to contribute to the Unemployment Insurance Fund, one of the criteria that would establish such an employer as part of the "formal sector" as defined by Statistics SA. None of the contractors interviewed were registered for purposes of Value Added Tax or contributing skills levies.

65 The Department of Labour official believed this was an exaggeration.
} 
workers?" If the farmer answered in the affirmative she would simply get together a team, there and then. She would not bother to register as an employer or for the purposes of the Compensation Fund. She would also not register the workers she employed.

The contractors claimed to know who the unregistered contractors were and which farms utilised their services. But they had not reported them to the Department of Labour. When asked why not, it was suggested they first needed proof. The Department of Labour official had a different explanation: it was simply that one contractor was not prepared to report another. Put it down to class solidarity amongst contractors.

All three had started their careers as contractors at about the same time, in the year 2000. All three worked from their homes, in the formal part of town, as sole proprietors of their businesses. One claimed to have registered as an employer from the outset. The other two did so a few years later. The modus operandi in all three cases was the same. Each had a business card that they handed out to farmers in the valley. The benefit for the farmer of utilising their services, according to $\mathrm{W}$, was that "we remove a big burden from his shoulders... Injuries are our responsibility."

Each also had a "permanent" team of workers who were registered with the Department of Labour. W printed a specimen contract of employment off his personal computer as proof of his compliance with labour legislation. Amongst this team, each "employed" a supervisor whose function it was to assemble the required number of workers when there was a contract. If more workers were required than in the team of "permanent" workers, "casuals" were employed. Because the farmer would invariably require the workers at short notice, it was not possible to register these "casuals" at the Department of Labour.

The contractors' demand was to be paid R10 per worker placed per day, but farmers would often not agree to this rate. More often they were paid R5 per worker per day. This was supposed to cover the administrative costs of employing and remunerating the workers as well as their transport to and from work. Sometimes their contract with the farmer was in writing: one such contract, with one of the large employers in the valley, described itself as an employment contract. ${ }^{66}$ At other times the contract would be verbal. The disadvantage of a verbal contract was that the farmer or his manager could, after an interval, try and enter into a separate contract with the supervisor, cutting out the contractor. This had happened to one of the contractors on two occasions.

It was from interviews with contractors that we first gauged the level of anger in the community, as well as getting an indication of the form it would take. If they were not given work, the contractors were planning a blockade of the town until their demands were met.

${ }^{66}$ We requested but were not provided with a copy of such a contract. 


\section{CONCLUSIONS}

The workers interviewed were employed at some 15 farms in the valley. This is a small proportion of the farms in the valley. But there was a degree of consistency in what the interviewees said. Some of what they had to say confirmed what other commentators had already found. Other things were surprising and at odds with what other commentators had said about the conditions of farm workers in general. But this, I suggest, only emphasises the need for understanding how local labour markets are organised and employment is structured. This has much to do with local circumstances, including whether or not workers are organised, and how effective their organisations are.

It is most surprising, for example, that the most vulnerable section of the workforce, migrants employed on a seasonal basis, should be earning a higher rate than seasonal workers resident on farms, and indeed many permanent workers. It suggests that farmers in the area were aware there was a time bomb in Stofland that was about to explode, and that wages were likely to be an underlying cause. It might also be prompted by a policy of divide and rule. Whether or not that is so, it also suggests that in an affluent farming area, such as this one, the wages imposed by the sectoral determination may set a ceiling rather than lift the floor.

It seems one can no longer assume that permanent workers on farms are mostly men, and that women access employment and housing through a male partner or male family member. ${ }^{67}$ It is of course still true that women are relegated to lower skilled and low-paying tasks, if one has regard to the residents of Stofland and elsewhere that supply seasonal labour from off the farm. Yet the influx of migrants is also affecting the gender composition of the workforce. Similarly, while the trend to employ off-farm seasonal labour has been documented, a trend to source "permanent" workers off farm may also be beginning.

But this study is too narrow in its scope to make definitive statements about trends. Its object, as indicated, was firstly to assess whether there had been a growth of indirect employment attributable to the labour regime, and its consequences. Secondly, it was to interrogate an argument that blames the labour regime for job losses. Thirdly, it was to consider the validity and usefulness of regarding farm workers as part of a "marginal working class". Each of these themes is dealt with below.

All indications are that indirect employment in the valley is massive, and one could hardly make a meaningful statement about employment there without having regard to its extent. This, in turn, raises a question about the usefulness of official statistics that differentiate between the "formal" and "informal" economy in other sectors but not in agriculture. It also illustrates the limitations of the distinction between "formal" and "informal", based on the registered status of the contractor. ${ }^{68}$

\footnotetext{
${ }^{67}$ Kritzinger, Barrientos \& Rossouw (fn 4 above) at 21.

${ }^{68}$ According to Statistics SA this is because of seasonal employment in the sector. The distinction between formal and informal is made on the basis of the "self perception" of respondents. However, respondents are informed that formal employment occurs where the employer is registered whereas informal employment "does not require the employer to be registered": Labour Force Survey, September 2007 (fn 6 above).
} 
Apart from difficulties in determining the registered status of a contractor (contractors may be, and frequently are, registered with one authority but not another), this is not the most important consideration if one is concerned with the conditions under which workers are employed.

All the workers interviewed in this study would properly seem to belong to the formal economy, in that they are paid the minimum wage and labour legislation is complied with. Yet to describe the Zimbabwean migrants as "formal" is to discount completely the precariousness of their position. In part this is because they are migrants. However, as employees, the roots of this precariousness are no different from those of other workers employed on a similar basis, and indeed the contractors that "employ" them. All are dependent on the farmers who provide the work. The employment of all (including the contractors) can be terminated at will by the farmers if it suits them to do so. Or the farmers can simply not provide them with work.

This is indeed a situation that can be attributed to the labour regime, insofar as the "sanctity of contract" still prevails and insofar as labour legislation has created the legal space employers have needed to restructure employment in this way. However, there was no inevitability about this development or its extent. Perhaps the most significant feature of the incorporation of agriculture into a new labour relations regime is that it was accomplished by and large without the involvement of the trade union movement. Farm workers were always and still are largely unorganised. ${ }^{69}$ As a consequence centralised bargaining, the bug-bear of employers, is unknown. To the extent that collective bargaining takes place at all it is at a local level and of very limited scope. In addition, both because of a weak union presence and the physical isolation of farm workers, agriculture has probably been affected less than other sectors by the dispute resolution system the LRA introduced. ${ }^{70}$

The legal space employers have utilised could be closed down in any of a number of ways, and pressure is mounting on government and courts to do so. Namibia has adopted legislation banning labour brokers, which has been overruled as being unconstitutional. ${ }^{71}$ But given the pervasiveness of the phenomenon a more pragmatic approach may be to regulate them or to introduce measures that would facilitate trade union organisation and collective bargaining. Probably what restrains government from doing so are the institutional pressures to deregulate from the World Bank and others, already referred to. However, in this case study at least, there is no hint of the labour regime or labour regulation causing job losses.

\footnotetext{
${ }^{69}$ Out of 254 registered trade unions an estimated fifteen have as an object, or are in fact, engaged in the agriculture sector (according to the list put out by the Department of Labour, updated at 15 August 2008). It is estimated that fewer than 6 percent of farm workers belong to trade unions (DFID-SA 2003).

70 Arguably the most significant increased cost in employing labour that legislation has introduced is the contingent cost of proceedings in the CCMA, when a dismissal is disputed on grounds of fairness: in other words, the perceived cost of terminating employment.

71 The ban in Namibian labour legislation was upheld by that country's High Court but overturned on appeal: see Africa Personnel Services (Pty) Ltd v Government of Republic of Namibia and Others (SA 51/2008) [2009] NASC 17 (14 December 2009) available at http://www.saflii.org/na/cases/NASC/2009/17.html (accessed 22 February 2011).
} 
What then of the notion of farm workers belonging to a "marginal working class", differentiated from a "core working class"? There is ample evidence of stratification in this study: between workers resident on farms and workers from off-farm, between permanent and seasonal workers, between workers directly employed by the farmer and those employed by the contractor, and even between workers employed by the same contractor (some are called "permanent", others are "casuals"). But these are not class distinctions. All are dependent for their livelihood on the same source.

There is also stratification between workers in agriculture and workers in manufacturing and other sectors of the economy. However, these different strata are in the same relation to those on whom they depend for a livelihood. If "marginal" is understood in a descriptive sense, to describe the consequences of disorganisation and disunity, it has some value. However, it makes neither descriptive nor analytic sense to regard workers in agriculture as part of a separate class.

The contractors are in an ambivalent position, much like supervisors and lower management. On the one hand they can be viewed as agents of externalisation. Yet they also perceive themselves as exploited, as indeed they are. It might be because the farmer or his consultant had a precedent of an employment contract at hand that the contractor has been referred to as "the employee" in a contract with the farmer. On the other hand, it is also a reflection of the power relationship between them. For this reason contractors, like farm workers, also need protection against wage competition, particularly those who pay the minimum wage. There are the unregistered contractors who are able to provide the same service at lower costs. Then there are the "spanners" who seem to be operating more as placement agencies, charging a once-off fee.

The problem of disunity amongst the working class has been underscored by socalled "xenophobic" violence that occurred in various parts of the country in May 2008. The N1 blockade in November 2007 might easily have spilled over into violence against migrants. As the community leader commented: "Tonight someone just has to say 'I've had enough of these Zimbabweans'. A Zimbabwean living here told me 'We are afraid.' "

This case study also illustrates why the term "xenophobia" has little explanatory value. A phobia is an irrational fear. There is nothing irrational about the competition between strata of the working class for scarce job opportunities.

The problem this study highlights is one of organisation. The function of a trade union is to organise the different strata and to prevent wage competition, through establishing collective bargaining arrangements. In the absence of such arrangements farm workers are not able to achieve the status of respected partners. Instead they are dependent on the largesse of the state. The paternalistic farmer is displaced by the paternalistic state.

For workers in indirect employment the workplace is not the farm where they are employed. Notionally, it is the house or shack where the contractor stays. If any single measure were adopted to facilitate trade union organisation, it would be to discard a legislative definition that gives rise to this anomalous situation and 
prevents such workers from exercising organisational rights. As matters stand, these workers have been disenfranchised as industrial citizens or the rural equivalent thereof. As a consequence, there has been a process of "passive deregulation" parallel to the extension of labour regulation to agriculture. ${ }^{72}$ If "the poor" are to resolve these problems, they need to rediscover the forms of organisation have historically relied on.

\section{POSTSCRIPT: NOVEMBER 2009}

In November 2009, a year after the field-work for this study was undertaken, at the start of the season there was violence against Zimbabwean migrants. Residents of Stofland expelled them from De Doorns and again blockaded the N1. None of the explanations advanced for their conduct, which boil down to migrants working for less than the minimum wage at the behest of farmers or labour brokers, are plausible in the light of this study. ${ }^{73}$ What is more plausible is that competition amongst labour brokers may have been a contributory factor or cause. After all, they represent influential individuals in the community, each with their own teams of workers that look to them to secure work, and can be easily mobilised. ${ }^{74}$

This does not detract from the failure of government to develop appropriate policies, both to regulate labour broking and to respond to the influx of foreign migrants, and a failure the part of civil society and the trade unions to develop forms of organisation that incorporate workers regardless of their origins.

\section{BIBLIOGRAPHY}

Benjamin P and Theron J "Costing, comparing and competing: Developing an approach to the benchmarking of labour market regulation" University of Cape Town, DPRU Working Paper 07/131 (2007).

Cockrell A “The Hegemony of Contract" (1998) 114 South African Law Journal 286.

\footnotetext{
72 Kerry Rittich "Vulnerability at work: Legal and policy issues in the new economy" (2004) 2430, cited in Tucker "Great expectations" defeated? The trajectory of collective bargaining regimes in Canada and the United States post-NAFTA" (2005) 26 Comparative Labor Law and Policy Journal 110.

${ }^{73}$ For example, it was alleged that labour brokers were hiring Zimbabweans because they will work for less than the minimum wage: Cape Times 18 November 2009.

${ }^{74}$ According to press reports, a study by the Forced Migration Studies Programme at the University of Witwatersrand on the causes of the xenophobic violence in May 2008 found that it was the "community leaders - the street committees, the comrades, the CPF (community policing forum)" that were organising the attacks on migrants: Cape Times 12 March 2009. [See also International Organization for Migration Towards Tolerance, Law, and Dignity: Addressing Violence against Foreign Nationals in South Africa IOM Regional Office for Southern Africa (2009) available at http://iom.org.za/site/index.php?option=com docman\&task=doc view\&gid=129 (accessed 22 February 2011) - Editor.]
} 
Conradie B "What do we mean when we say casualisation of farm work is rising: Evidence from fruit farms in the Western Cape" Agrekon 46(2) (2007) 173.

Du Toit A and Ally F "The externalization of casualisation of farm labour in Western Cape horticulture", Centre for Rural Legal Studies, UWC, Research Report No. 16, (2003); available at http://www.plaas.org.za/pubs/downloads/RR\%2016 \%20du\%20Toit\%20and\%20Ally\%20Web.pdf (accessed 22 February 2011).

Du Toit A "Forgotten by the Highway: Globalisation, Adverse incorporation and chronic poverty in a commercial farming district." PLAAS Chronic Poverty and Development Policy Series No. 4 (2004); available at http://www.chronicpoverty.org/uploads/publication files/WP49 duToit.pdf (accessed 22 February 2011).

Edwards R et al "The position of women workers in wine and deciduous fruit value chains" SANPERI Development Consultants; report commissioned by Women on Farms Project (2008).

Graaff D "Farming in the Hexriver Valley" SALDRU Farm Labour Conference (September 1976) Paper No. 42.

Greenberg S "Women workers in wine and deciduous fruit global value chains" (2003). Report for WFP 2003.

Jacobs E "Farm Workers, Job Security and Labour Contractors" Elsenburg Journal 5(22) (2008).

Barrientos S \& Kritzinger A "Squaring the circle: global production and the informalization of work in South African fruit exports" (2004) 16 Journal of International Development 81.

Kritzinger A, Barrientos S \& Rossouw H "Global Production and flexible employment in South African horticulture: experiences of contract workers in fruit exporters" Sociologia Ruralis 44(1) (2004) 17.

Kritzinger A "Global markets, employment restructuring and female labourers on Western Cape fruit farms" Acta Academia 37(1) (2005) 99.

Le Roux R "Agricultural Workers: a historical and contemporary perspective." University of Cape Town, Institute of Development and Labour Law Monograph Series 1/2002 (2002).

Levy B "Seasonal migration in the Western Cape" SALDRU Farm Labour Conference (September 1976) 87.

Jara M "Monitoring Compliance with the Sectoral Determination for farm workers in 5 Western Cape Farming Districts" (2006) Report Commissioned by Women on Farms Project.

Naidoo L, Klerck G \& Manganeng L "The 'bite' of a minimum wage: enforcement of and compliance with the sectoral determination for farm workers" (2007) 31 South African Journal of Labour Relations 25. 
Seekings J \& Nattrass N Class, Race and Inequality in South Africa Yale University Press, New Haven (2005)

Van der Burg "Going for broke: a case study of labour brokerage on fruit farms in Grabouw" Centre for Rural Legal Studies, Stellenbosch, Research Report (2008).

Theron J, Godfrey S \& Lewis P "The rise of labour broking and its policy implications" Institute of Development and Labour Law, University of Cape Town, Development and Labour Law Monograph Series, 1/2005 (2005).

Theron J, Godfrey S \& Visser M “Globalization, the impact of trade liberalization, and labour law: the case of South Africa."' ILO, International Institute for Labour Studies, Discussion Paper DP 178/2007 (2007).

Theron J "The shift to services and triangular employment: implications for labour market reform" (2008) 29 Industrial Law Journal 1.

Van der Merwe S, Van Huyssteen LF, Reinecke MFB \& Lubbe GF Contract: General Principles 3 ed Juta (2007). 